\title{
Наталя Зацепіна
}

Національний університет «Запорізька політехніка»

\section{Паломництво як соціокультурний феномен на прикладі основних світових релігій (філософський підхід)}

В статті досліджено паломницький туризм як сучасний соціокультурний феномен на прикладі основних світових релігій. Зроблено спробу пояснити та визначити його особливості, проводячи паралель між релігійним (культурним) туризмом і паломництвом. Визначено, що в основі сучасного паломництва знаходиться давня релігійна традиція, яка стає глобальним соціокультурним явищем на тлі послаблення ролі світових політичних ідеологій. Крім того, паломництво сприяє розширенню сучасних міжцивілізаційних контактів, роблячи всі куточки планети доступними для паломницьких потоків, але це кардинально змінює характер міжособистісної комунікації та відбивається на духовних настроях сучасних прочан. Також досліджено різні форми сучасного паломництва, їх особливості та прояви у міжкультурній комунікації віруючих протягом періоду їх релігійних подорожей. 3 іншого боку, визначено, що існуючі сучасні домінуючі світові тенденції у наскрізній комерціалізації, які перетворюють ресурси, національні культурні та релігійні святині у товари. Тому релігійні подорожі хоча і мають свої особливості, але однаково стосуються надання традиційних туристських послуг, як і інші тури, а паломництво стає частиною туристичного бізнесу. Розглядаючи паломництво як соціокультурне явище у світових релігіях, звернено окрему увагу на органічне поєднання національного та наднаціонального, тобто практику цієї давньої традиції, загальної для певної конфесії. Для більшого розуміння принципів формування потоків релігійного туризму зроблено аналіз конфесійного розмежування територіальних релігійних систем на прикладі Європи. Визначено паломництво як перспективний вид туризму, який може вийти на міжнародний рівень, стати головною визначною пам'яткою як окремих регіонів, так і цілої країни та відігравати важливу економічну роль в розвитку певної території. Саме тому сучасне паломництво потребує розвитку й популяризації.

Ключові слова: паломництво, релігійний туризм, світові релігії, культові практики, паломницькі традиції, сакральні місия, ритуали

Nataly Zatsepina

Zaporizhzhia Polytechnic National University

\section{Pilgrimage as a socio-cultural phenomenon on the example of major world religions (philosophical approach)}

The article examines pilgrimage tourism as a modern socio-cultural phenomenon on the example of major world religions. An attempt is made to explain and determine its features by drawing a parallel between religious (cultural) tourism and pilgrimage. It is determined that the basis of modern pilgrimage is an ancient religious tradition, which is becoming a global socio-cultural phenomenon against the background of the weakening role of world political ideologies. In addition, pilgrimage contributes to the expansion of modern intercivilizational contacts, making all corners of the planet accessible to pilgrimages, but it dramatically changes the nature of interpersonal communication and affects the spiritual mood of modern pilgrims. Various forms of modern pilgrimage, their features and manifestations in intercultural communication of believers during the period of their religious travels are also studied. On the other hand, it is determined that the current modern world dominant trends in end-to-end commercialization, which turn resources, national cultural and religious shrines into goods. Therefore, religious trips, although they have their own characteristics, but equally apply to the provision of traditional tourist services, as well as other tours, and pilgrimage becomes part of the tourism business. Considering pilgrimage as a socio-cultural phenomenon in world religions, special attention is paid to the organic combination of national and supranational, ie the practice of this ancient tradition, common to a particular denomination. To better understand the principles of formation of religious tourism flows, an analysis of the confessional delimitation of territorial religious systems on the example of Europe. Pilgrimage is defined as a promising type of tourism that can reach the international level, become a major attraction of both individual regions and the country as a whole, and play an important economic role in the development of a particular area. That is why modern pilgrimage needs development and popularization.

Keywords: pilgrimage, religious tourism, world religions, cult practices, pilgrimage traditions, sacred places, rituals 


\section{Постановка проблеми.}

$\mathrm{y}$ різних релігіях світу присутне явище, яке часто визначається українською мовою як «паломництво». Туризм у сучасному світі $\epsilon$ невід'ємною частиною людського життя, а релігійний туризм, до складу якого входить паломництво, відповідає зростаючим духовним потребам людства. У більшості релігій паломництво відіграє традиційну місіонерську роль, сприяючи утвердженню релігійних істин в суспільстві, залученню до тієї чи іншої релігії. Специфіка паломництва визначається особливостями релігійної свідомості віруючих, що в свою чергу пов'язано 3 характером віроповчальної доктрини i культової практики тих чи інших релігійних напрямів. Для розгляду ж самого явища паломництва на сьогодні виникає ряд психологічних, соціологічних, культурологічних та релігієзнавчих питань. У кожній релігії, як і в кожній культурі, сформована власна традиція паломництва як духовної місії вірян.

Паломництво слід розглядати як універсальну давню релігійну традицію, яка зберігається як одне 3 найбільших та тих, що активно розвиваються, сучасних соціокультурних явищ, заснованих на закономірності повернення суспільного інтересу до взаємодії локальних цивілізацій у глобалізованому світі, на тлі послаблення ролі політичних ідеологій. Релігійне паломництво, як давня культурна традиція, змогло зберегти свою незмінну сутність протягом тисячоліть і стало невід'ємною частиною сучасного світу. Зовнішні умови для релігійних подорожей змінилися, але цілі та зміст паломництва у світових релігіях залишаються незмінними.

Постійне розширення паломницьких подорожей сьогодні $€$ однією 3 найважливіших сфер міжцивілізаційного контакту, що яскраво проявляє багатогранні тенденції нашого часу. 3 одного боку, це «стирання» національних кордонів та найважливіших етнокультурних відмінностей, видиме «пошкодження» суверенітету та розповсюдження «типових» субкультур, які змінюють спосіб життя окремих народів, а також розвиток глобальної транспортної та туристичної інфраструктури на єдиній основі. Все це нескінченно розширює можливості будьяких, включаючи й міжконтинентальні зав'язки, роблячи всі куточки планети доступними для паломницьких потоків, але кардинально змінюе характер міжособистісної комунікації та відбивається на духовних настроях сучасних прочан. У той же час існують домінуючі тенденції у наскрізній комерціалізації, яка перетворює ресурси, національні культурні та релігійні святині у товари, а паломництва на частину туристичного бізнесу. 3 іншого боку, це перш за все повернення до культурних та цивілізаційних витоків, справжній інтерес нових поколінь до культуроутворюючих релігій та підйом традиційної цивілізаційної, етнічної та громадянської самоідентифікації, що стає природною і адекватною реакцією особистості на руйнівний зовнішній вплив (Расторгуев, 2007 , c. 60-61).

Незважаючи на загальну назву, паломницькі традиції та критерії їх оцінки в різних релігіях суттєво відмінні, тому буквально цей термін найчастіше вживається відповідно стосовно християнського паломництва. Традиція паломництва до святих місць відроджується не лише серед православних християн, а й серед послідовників інших великих релігій, наприклад, мусульман та буддистів. У той же час паломництво представників різних релігій, включаючи паломництво за «зустрічними маршрутами», де перетинаються різні паломницькі маршрути (наприклад, Срусалим, Дамаск, Константинополь, Делі та інші), де прочани різних релігій подорожують і прямують до святих місць, та де паломники з різних релігій та культур активно взаємодіють між собою, стало масовим явищем та вплинуло на всі сфери суспільного життя в останні десятиліття, диктуючи необхідність розглядати паломництво як соціокультурне явище на стику різних наукових дисциплін. Беручи до уваги інтенсивність міжкультурних та міжконфесійних контактів, які постійно виникають у період паломництва, зростає необхідність вивчення та пояснення особливостей міжкультурної комунікації віруючих протягом періоду релігійних подорожей. 


\section{Аналіз досліджень і публікацій.}

Розглядаючи питання про ступінь розробленості зазначеної проблеми, слід виходити 3 того, що роль святинь у формуванні особистості та в житті суспільства $\epsilon$ одним із найскладніших питань на стику наук філософії, культурології, історії та релігієзнавства. Найбільш розробленим науковим напрямом в нашій країні стали дослідження 3 різних аспектів історії християнського паломництва. Більша частина досліджень була представлена або зі складання та узагальнення емпіричних спостережень, або прикладів подорожей паломників у попередні періоди, або путівників, а також описів священних місць.

Тема паломництва завжди привертала увагу культурологів, філософів, географів, богословів, релігієзнавців, мистецтвознавців i антропологів, серед них: В. М. Воробйов, С. В. Гнутова, В. М. Жівов, Д. Н. Замятін, Л. А. Ілюніна, Е. А. Калужнікова, Г. М. Керімов, О. В. Кириченко, архієпископ Марк (Головков), I. В.Моклецова, А. Е. Мусін, А. С. Панарін, А. А. Пєскова, М. Б. Піотровський, Х. В. Поплавська, Г. В. Попов, Ю. А. П’ятницький, В. Н.Расторгуєв,А. В.Риндіна, В. Н.Топоров, Т. Б. Щепанская, Е. М. Юхименко. Питання паломництва і релігійного туризму в останні роки розглядали вчені, які займаються комплексними науковими дослідженнями в туристській сфері, серед них: Г. В. Антюфеєв, Ю. К. Байназаров, М. Б. Биржаков, I. В. Брандт, С. Ю. Житеньов, П. І. Караневський, М. С. Кірова, В. С. Новиков, Ю. С. Путрик, С. І. Реснянская, Т. Т. Христов. Але ж сутнісні аспекти та особливості організації релігійного туризму в світових релігіях не достатньо вивчені.

Тому метою дослідження $є$ визначення сутності та особливостей розвитку паломництва та релігійного туризму в основних релігіях світу.

\section{Основний матеріал.}

В останні роки ідея паломництва набула широкого поширення як явище, яке складається 3 двох взаємопов'язаних форм, не зовсім коректних, тобто невідповідних традиційним поглядам. Перша форма - це релігійне паломництво до святих місць представників різних релігій, освячене багатовіковими традиціями шанування та поклоніння. Друга форма - світські подорожі (паломництво) туристів, незважаючи на їх релігійну приналежність, до різних, як правило, монументальних, пам'ятних та інших релігійних та світських об’єктів. Щоб підтвердити цей підхід, його послідовники пропонують розглядати паломницький ритуал як священний акт, характерний як для поклоніння священному місцю певної релігії, так і для відвідування світського об'єкта. Як правило, такий підхід не передбачає чіткого розрізнення священного, тобто сакрального, від псевдосакрального змісту самої дії, чого насправді неможливо досягти без наявності певної релігійної культури суспільства або принаймні його частини.

Звичайно, ритуали можуть бути як релігійними, так і світськими, але слід підкреслити, що вони не можуть бути однаковими за своїм змістом. Між тим, сакральними місцями вважають місця, які мають релігійне значення для певних релігійних громад. До них належать (але не обмежуються ними) культові місця, кладовища та храми, а також їх оточення, якщо вони є невід'ємною частиною цих місць. Тобто, сакральні місця мають чітко визначені межі, які визначаються традицією кожної релігійної громади, але ж визнається, що будь-яке сакральне місце може мати релігійне значення для багатьох релігійних груп.

Прихильники світської інтерпретації сутності паломництва покладаються на надзвичайно широке розуміння ритуалу, який нібито «інтерпретується сучасною наукою як історично усталена форма складної символічної поведінки» (Калужникова, 2006, с. 15). Однак при відвідуванні світських об'єктів, наприклад, монументальних скульптур політиків, мавзолеїв, меморіалів війни та пам'ятників, що належать представникам сучасного масового мистецтва, не спостерігається наявність складних символічних ритуалів, звичайно, якщо покладання квітів або виконання пісень не розглядати як такі. Така типологія є однобічною та неефективною, оскільки базується на формальній подібності соціокультурних та релігійних явищ, неоднорідних за своїм змістом, таких 
як паломництво та туризм.

Тут варто зазначити, що різні види туризму визначаються відповідно до основної мети туристичної подорожі. Багато сучасних вітчизняних та зарубіжних вчених та експертів відносять до релігійного туризму пізнавальні подорожі, визнаючи, що більшість туристичних поїздок зазвичай мають декілька цілей. Наголошуючи, що туризм i паломництво - це не одне i те ж та є різними соціокультурними видами діяльності, необхідно визнати той факт, що термінологічна основа паломництва запозичена у туристичної галузі, як «паломницький туризм», «світське паломництво», «паломницький продукт», «паломницький тур» тощо, здається необгрунтованою. Визнаючи необгрунтованість використання терміну «світське паломництво», важливо зазначити, що за усвідомленими спробами змішувати різні соціокультурні діяльності існує тенденція до обмеження культурної та цивілізаційної різноманітності людської діяльності, що характерно для ідеології та практики глобалізованого світу. Це спроба встановити можливість реалізації так званих універсальних культурних механізмів порядку i призводить до значного спотворення уявлення про саме явище релігійного паломництва. Таким чином, необхідно наголосити, що слід уникати терміну «світське паломництво», яке за своєю суттю $є$ туризмом, тобто принципово іншим соціальним явищем, яке можна визначати терміном «релігійний туризм».

Таким чином знищення самобутності та внутрішньої цінності ідеї релігійного паломництва як традиційного соціокультурного явища неминуче призводить до втрати та розмивання його унікальної природи, що сягає багатовікового минулого. Слід також зазначити, що, незважаючи на різні заяви прихильників так званого «світського паломництва», віруючі будь-якої релігії в реальному житті ніколи не визнають мирські об'єкти святинями, яким слід поклонятися. Те саме стосується атеїстів чи людей, яким через професійну необхідністьдоводиться відвідувати світські меморіали чи інші пам'ятні об'єкти, вони ніколи не визнають їх справжнім святим місцем та об'єктом поклоніння. У зв'язку 3 цим, наступне визначення паломництва як соціокультурного та релігійного явища, яке існує у багатьох світових та національних релігіях, можна вважати найбільш доцільним. Паломництво - це традиційна форма релігійної діяльності, яка полягає у подорожі віруючих для відвідування та поклоніння святиням за межами їх постійного місця проживання.

Туризм, в свою чергу, - це подорож 3 пізнавальними чи будь-якими іншими цілями, окрім заробляння грошей в місці відвідування. Одним 3 найпопулярніших видів туризму є релігійний туризм. Головний пізнавальний об'єкт в цьому виді туризму це історія священних місць, побут святих, архітектура, знайомство 3 мистецтвом церкви. Все це визначено в екскурсійній поїздці, яка $\epsilon$ найважливішим елементом подорожі для туриста. Екскурсійна поїздка може бути частиною й паломництва, але вона не $\epsilon$ головним чи обов'язковим елементом, а може бути допоміжною. Найголовніше в паломництві - це богослужіння, молитви i релігійне поклоніння святиням. Будьяке паломництво - частина релігійного життя кожного віруючого. У процесі паломництва головне під час молитви - це не зовнішне виконання ритуалів, а духовне оновлення, яке відбувається у християнина, у мусульманина чи у буддиста як переважання певного духовного настрою у серці. Характеристика будь-яких паломників значною мірою визначається рисами релігійної свідомості віруючих. Тому не менш важливим $\epsilon$ розуміння відмінностей між визначеннями різних напрямів релігійного туризму (див. табл. 1).

Якщо враховувати, що паломницькі тури - це довгі подорожі, куди їздять лише віруючі, а пізнавальні поїздки не пропонуються, тоді екскурсійні тури призначені лише для туристів, тур повинен бути частиною як тривалої подорожі, так i короткого перебування у подорожі. У таблиці 3 визначені різні типи поїздок та надано характеристику кожному 3 видів паломницького туризму (див. табл. 2).

Виходячизусьоговищенаведеного, можна зробити висновок, що сучасні подорожі (релігійні, не виняток) безпосередньо пов'язані 3 необхідністю надання туристам 
Релізійні подорожі як вид туристськой діяльності

\begin{tabular}{|c|c|c|}
\hline $\begin{array}{c}\text { Вид } \\
\text { туристської } \\
\text { діяльності }\end{array}$ & Визначення поняття & Джерело \\
\hline Паломництво & $\begin{array}{l}\text { як один із аспектів духовної діяльності церкви, маючи давні } \\
\text { коріння, є формою богослужіння та поклоніння пастви, } \\
\text { відвідування богослужінь у святих місцях та здійснення } \\
\text { молитовного спілкування з віруючими інших помісних церков як } \\
\text { вираження єдності та соборності Православної церкви за вченням } \\
\text { Святого Писання, Вселенських соборів та Святих отців. }\end{array}$ & $\begin{array}{l}\text { Матеріали } \\
\text { міжнародної } \\
\text { паломницьк } \\
\text { ої } \\
\text { конференції. } \\
\text { Київ. } 22 \\
\text { жовтня } 2010 \\
\text { р. }\end{array}$ \\
\hline $\begin{array}{l}\text { Релігійний } \\
\text { туризм }\end{array}$ & $\begin{array}{l}\text { вид діяльності, пов’язаний } 3 \text { наданням послуг і задоволенням } \\
\text { потреб туристів, які прямують до святих місць і релігійних центрів, } \\
\text { що знаходяться за межами звичайного для них середовища. }\end{array}$ & $\begin{array}{l}\text { (Бабкин, } \\
\text { 2008) }\end{array}$ \\
\hline Туризм & $\begin{array}{l}\text { тимчасові виїзди (подорожі) людей в іншу країну або місцевість, } \\
\text { відмінну від місця постійного проживання на термін від } 24 \text { годин } \\
\text { до } 6 \text { місяців протягом одного календарного року або з вчиненням } \\
\text { не менше однієї ночівлі в розважальних, оздоровчих, спортивних, } \\
\text { гостьових, пізнавальних, релігійних та інших цілях без заняття } \\
\text { діяльністю, оплачуваною з місцевого джерела (франц. tourisme - } \\
\text { від tour - прогулянка, поїздка). }\end{array}$ & $\begin{array}{l}\text { (Биржаков, } \\
\text { 2020) }\end{array}$ \\
\hline
\end{tabular}

різноманітних життєво важливих послуг: харчування, транспортування, оформлення документів. Організація релігійних турів та їх характеристика, хоча i дуже специфічна, полягає в тому, що туристам необхідно належним чином надати повний спектр туристських послуг. Це говорить про те, що при чітко дозованому насиченні релігійного туру класичним набором послуг розміщення, харчування, транспортування, оформлення

Типи релігійних подорожей

\begin{tabular}{|c|c|}
\hline Тип подорожі & Приклад \\
\hline Паломництво & $\begin{array}{l}\text { такі подорожі завжди включають богослужіння (як правило, } \\
\text { ритуальне), читання акафістів (славлення), молитви (Бабкин, 2008, } \\
\text { с. 35-39), також присутній його історичний аспект, але він } \\
\text { пов'язаний в основному } 3 \text { подіями, безпосередньо пов’язаними } 3 \\
\text { православ'ям у регіоні: появою монастирів, життям святих, } \\
\text { переслідуванням, захистом монастирів від ворогів. Перш за все, це } \\
\text { Росія, Україна, Білорусь, Сербія, Італія, Афон (Греція), Свята земля } \\
\text { (Ізраїль) (Житенев, 2012, с. 19-25). }\end{array}$ \\
\hline $\begin{array}{l}\text { Паломництво зі } \\
\text { значною часткою } \\
\text { православного } \\
\text { паломницького } \\
\text { туризму } \\
\text { (Христов, 2009, } \\
\text { с. 35-49) }\end{array}$ & $\begin{array}{l}\text { такі подорожі відбуваються переважно Європою: Німеччина, } \\
\text { Франція, Іппанія, Португалія та Північна Америка, у яких є всі } \\
\text { ознаки паломництва (ритуал, зустрічі зі священиками та } \\
\text { прихожанами місцевих церков, молитви про мандрівників), але крім } \\
\text { цього, гід надає не лише інформацію про дохристиянську історію, } \\
\text { про яку відомо не лише за проповіддю Святого апостола Павла. У } \\
\text { Парижі паломники відвідають не тільки місце збереження } \\
\text { Тернового вінця Спасителя в соборі Нотр-Дам-де-Париж, але й } \\
\text { Ейфелеву вежу, легендарний Монмартр та Єлисейські поля. У США } \\
\text { паломники не лише відвідуватимуть християнські церкви та } \\
\text { монастирі, але й побачать Ніагарський водоспад та Великий } \\
\text { Каньйон (Христов Т., 2009, с. 19-25). }\end{array}$ \\
\hline $\begin{array}{l}\text { Поїздки } \\
\text { переважанням } \\
\text { паломницького } \\
\text { християнського } \\
\text { туризму, хоча } \\
\text { паломницька } \\
\text { складова } \\
\text { залишається } \\
\text { відчутною }\end{array}$ & $\begin{array}{l}\text { наприклад, поїздка в Ефіопію. Ефіопська церква - коптська. Вона } \\
\text { відрізняється від грецької православної церкви (включаючи РПЦ) } \\
\text { за догматикою, тому участь у спільних богослужіннях канонічно } \\
\text { забороняється. Однак це найцікавіша країна } 3 \text { християнської точки } \\
\text { зору, де зберіглися чиста щирість іконопису, старовинні храми, } \\
\text { загальне шанування Христа, Марії та святих, які збереглися у } \\
\text { майже повністю ізольованій від християнського світу країні. }\end{array}$ \\
\hline
\end{tabular}


документів, тощо, його зміст зовсім не страждає (Печерица, 2014).

Для аналізу конфесійних вимірів сучасних видів релігійних подорожей найзручніше розглядати паломницькі практики в трьох основних світових релігіях - християнстві, буддизмі та ісламі. Розглядаючи паломництво як соціокультурне явище у світових релігіях, слід також звернути увагу на органічне поєднання національного та наднаціонального, тобто практику цієї давньої традиції, загальної для певної конфесії. Також процес формування загально важливих священних місць для кожної релігії та їх мемориалізація важливі для розуміння появи масового паломництва у світових релігіях. Освячення та подальше вшанування пам'яті місць, пов'язаних із земним життям Христа, Будди та пророка Моххамеда, стали загальними чинниками виникнення та розвитку паломництва та ритуальної культури поклоніння у трьох світових релігіях.

Для аналізу формування паломницьких напрямів не менш важливо розуміння про конфесійне розмежування територіальних релігійних систем. Так, наприклад, Європа в конфесійному розмежуванні територіальних релігійних систем, які охоплюють великі території континенту, утворюючи континентальні релігійні поля, дуже різна (Печерица, 2014). Сучасний конфесійногеографічний склад європейських регіонів виглядає наступним чином (див. табл. 3 ).

Конфесійна структура населення Свропи

\begin{tabular}{|c|c|}
\hline Макрорегіони & Конфесійна структура населення \\
\hline $\begin{array}{l}\text { Північний } \\
\text { макрорегіон }\end{array}$ & $\begin{array}{l}\text { Значна перевага протестантів (лютеран, англікан, пресвітеріан). У } \\
\text { більшості країн протестантські церкви мають державний статус } \\
\text { (Великобританія, Данія, Ірландія, Норвегія, Фінляндія). Православні } \\
\text { церкви становлять важливу релігійну меншину в країнах Балтії (Латвія, } \\
\text { Естонія). }\end{array}$ \\
\hline $\begin{array}{l}\text { Західний } \\
\text { макрорегіон }\end{array}$ & $\begin{array}{l}\text { Переважають латино-католики, знаходяться найважливіші центри та вузли } \\
\text { для активізації релігійного життя, у тому числі й світовий центр } \\
\text { католицизму - Ватикан (Франції, Австрії, Бельгії, Ірландії, Італії, Іспанії, } \\
\text { Люксембурзі, Португалії), а протестантів і православних невелика } \\
\text { кількість, до нехристиянських релігій належать іудаїзм та іслам. }\end{array}$ \\
\hline $\begin{array}{l}\text { Середній } \\
\text { Свропейський } \\
\text { макрорегіон }\end{array}$ & $\begin{array}{l}\text { Співвідношення приблизно рівних за чисельністю спільнот католиків і } \\
\text { протестантів (Нідерланди, Німеччина, Швейцарія). }\end{array}$ \\
\hline $\begin{array}{l}\text { Центральному } \\
\text { макрорегіон }\end{array}$ & $\begin{array}{l}\text { Найбільшим впливом користується Римокатолицька Церква (Литва, } \\
\text { Польща, Чехія, Словаччина, Угорщина, Словенія, Хорватія). Релігійними } \\
\text { меншинами є лютерани, реформати, православні, греко-католики. }\end{array}$ \\
\hline $\begin{array}{l}\text { Південно-Східний } \\
\text { макрорегіон }\end{array}$ & $\begin{array}{l}\text { Перевага православних (Румунія, Молдова, Болгарія, Греція, Сербія, } \\
\text { Чорногорія, Македонія, Боснія й Герцеговина, Албанія). Найбільшими } \\
\text { релігійними меншинами є мусульмани і католики. Ісламу дотримується } \\
\text { більшість етнічних албанців, турків та ісламізовані слов'яни. Вплив } \\
\text { протестантських церков незначний. У Румунії та Молдові є значні } \\
\text { спільноти російських старообрядців. }\end{array}$ \\
\hline $\begin{array}{l}\text { Східний } \\
\text { макрорегіон }\end{array}$ & $\begin{array}{l}\text { Входять три східнослов'янські країни (Білорусь, Україна, Росія), } \\
\text { домінуючим релігійним напрямом в яких є православ'я. Також } \\
\text { історичними релігійними спільнотами є католики (латинського та } \\
\text { візантійсько-українського обрядів, які відносяться до Римо-Католицької та } \\
\text { Греко-Католицької Церкви). Релігійними меншинами в Росії є мусульмани } \\
\text { та буддисти-ламаїсти. Також проводять активну місіонерсько-- } \\
\text { проповідницьку діяльність протестантські спільноти, які заповнюють } \\
\text { духовний вакуум після занепаду державного атеїзму з розпадом } \\
\text { Радянського Союзу. У цьому відношенні найбільш істотні конфесійні } \\
\text { трансформації відбуваються в Україні. }\end{array}$ \\
\hline
\end{tabular}


Відповідно, визначення Європи як континентузагальної християнськоїкультури відповідно до католицької ініціативи не сприймається однаково православними та протестантами, оскільки християнську Свропу формували не лише католицький Рим, ай Візантія. Протестантська реформація та католицька контрреформація також дали поштовх для іiі подальшого розвитку. Зрештою, західне та східне християнство ототожнювало себе 3 різними суспільнополітичними та культурно-релігійними системами та цінностями. Виходячи 3 цього історичного контексту, католицьке визначення «загальних християнських коренів Європи від Атлантики до Уралу» не стало вирішальною домінантою у православно-католицькому діалозі. Саме тому й визначення Європи як християнської спільноти творцями Об'єднаної Європи не було належним чином затверджено, і тому це визначення було вилучене 3 проекту Конституції.

Християнство - найбільша релігія у світі, яка нараховує близько 2 мільярдів прихильників (майже третина населення світу - християни) та складається 3 двох основних напрямків: Православна Церква (Східна Церква) та Католицька Церква (Західна Церква). Багато вчених також визначають протестантизм, монофізитизм та несторіанство, а також численні релігійні рухи, напрями та секти як сфери, які також мають відношення до християнства. Насправді протестантизм був лише напрямком західної церкви, тобто виділився з католицизму, а монофізитизм та несторіанство - єресі, засуджені як східною, так і західною церквами.

Поняття «паломник» походить від тоді, коли називали паломниками учасників хресного ходу на Святу Землю на свято входу Господа в Єрусалим (інакше це свято також називається тижнем Вая або Вербною неділею в давньослов'янській православній традиціï). Пізніше паломниками стали називати молитвословів, які подорожували не лише до Єрусалиму, але й до інших християнських святинь. Так, християнина, який відвідує святі місця за межами свого постійного проживання, щоб поклонятися святині, називають паломником (Словарь православного паломника, 2007).
Християнський паломницький туризм має особливе значення та грає певні важливі ролі у суспільному житті: духовнопросвітницька роль (під час подорожі паломники дізнаються про історію місць, які вони відвідали, їх роль у духовному житті людей; про особливості проведення служби, про спадщину святих та старців); загальноосвітня роль (монастирі були та залишаються культурно-історичними центрами, мають музеї, які відображають життя та традиції різних історичних періодів на території багатьох регіонів); місіонерська роль (поїздки по святих місцях сприяють воцерковленню багатьох нерелігійних людей); благодійницька роль (під час паломницьких турів паломники здійснюють благодійну фінансову допомогу та пожертви).

Хадж - це велике паломництво мусульман до святинь в Мецці таії̈ околиць (гори Арафат, долини Муздаліфа та Міна), а також Медині, його здійснюють у визначений час, на початку дванадцятого місяця «зуль-хіджа». Це один 3 чотирьох священних місяців заборон (раджаб, зуль-хіджа, зуль-када, мухаррам), який особливо цінний першими десятьма днями, коли бажано тримати піст. Час паломництва визначається за ісламським календарем, а точні дати варіюються від року до року (Хадж 2020: когда пройдет и сколько будет стоить, 2020), у 2020 році паломництво до Мецці припало на липеньсерпень. Хадж - це набір обов'язкових ритуалів, які наближають мусульманина до Всемогутнього Бога і символізують віру, єдність та рівність паломників. Це п'ятий стовп ісламу після Шахади, молитви (намаз) (Хадж 2020: паломничество в Мекку, 2020), податку (закят) і посту (саум).

Слідзазначити,щозаразхаджздійснювати набагато простіше, ніж в минулі століття, завдяки авіасполученню. Сів на літак та через кілька годин ти вже у священній Мецці. Раніше потрібно було місяцями добиратися i по морю і по суші. Сучасний хадж простіший, більш комфортний, але відповідальність перед Богом стала навіть більша. Для всіх країн, які відправляють своїх людей в хадж, профільне міністерство Саудівської Аравії надає певну кількість місць. 3 Туреччини, Пакистану, Індонезії дуже багато бажаючих, i для того щоб священну Мекку не 
заполонили паломники тільки з цих країн, встановлюються обмеження.

В даний час особлива увага приділяється духовнимвченняміпрактикам Сходуувсьому світі. Безперечно, серед найпопулярніших релігій слід назвати буддизм, найдавнішу 3 трьох світових релігій, що виникла в 1 тисячолітті до нашої ери на кордоні сучасної Індії та Непалу. Сьогодні буддистський світ охоплює багато країн Південної, ПівденноСхідної та Східної Азії та низку регіонів Pociï, у США та західноєвропейських державах існує багато буддистських храмів та громад. За оцінками експертів, у сучасному світі налічується близько п’ятисот мільйонів буддистів, і переважна більшість 3 них проживає в Азії.

Традиція паломництва в буддизмі (Накхор) має найдавнішу історію завдяки своєму виникненню набагато раніше порівняно 3 іншими світовими релігіями. Спочатку ритуальна сторона буддизму була надзвичайно слабкою та аскетичною. Однак, відповідно до природного механізму розвитку будь-якої релігії, в перші століття існування буддистської спільноти ритуал починав набувати все більшого значення. Але зараз буддизм є надзвичайно складною та розгалуженою ритуальною системою вшанування святинь, яка має особливу специфіку в різних буддистських традиціях (школах).

Буддійське паломництво вважається найважливішою частиною релігійного життя тих, хто належить до цієї світової релігії. Ідея проведення буддистських паломницьких та ритуальних обрядів виникла в Індії у 5 столітті до нашої ери та стала одним з головних проявів релігійних настроїв усіх буддистів. $\mathrm{y}$ буддизмі паломництво складається 3 відвідування святих місць для отримання духовних знань, а результатом $є$ поклоніння та повага до вищих сил. За каноном паломники - це ті, хто залишили світ, а під час паломництва вони піднімаються до неба сходами. Для більшості віруючих буддистів благоговійне ставлення до предмету поклоніння служить накопиченню благодаті, i той чи інший праведник $\epsilon$ заступником, який допомагає людині розірвати цикл переродження. При вивченні цього явища виділяють найбільш відвідувані релігійні місця: сакральні міста, особливі святі храми, місця поховань та кремації Вчителів, які вже залишили цей світ.

Для буддиста основною причиною паломництва $\epsilon$ бажання збільшити свої чеснотиі, такимчином, принести користьусім живим істотам та обдарувати всіх заробленою святістю. Особиста причина може полягати в тому, щоб довго і важко спокутувати гріхи свого минулого і теперішнього життя, накопичувати доброчесні справи для більш сприятливого майбутнього народження або отримати захист у цьому житті, особисто поклоняючись богам. Під час паломництва віруючі тимчасово складають чернечі обітниці i, таким чином, спокутують своє земне існування. Загалом, паломницькі каравани були численними і складалися 3 понад сотні людей, більшість 3 яких були озброєні, оскільки подорожі по величезних регіонах Середньої Азії були дуже небезпечними 3 давніх часів. Паломники обирали керівника каравану, який повинен був бути досвідченою людиною, знати маршрут подорожі, встановлювати час від'їзду, встановлювати місце для ночівлі, стежити за тим, щоб ніхто не залишався в небезпечному місці, організовував оборону людей у разі нападу, представляв інтереси паломників перед місцевою владою.

Маршрути паломників були розроблені для відвідування буддистських святих місць по дорозі, включаючи монастирі, де вони могли помолитися, запастись їжею та уточнити маршрут. Рухаючись, паломники вивішували на субурганах та молитовних циліндрах (барабанах) різнокольорові релігійні прапори. Буддистські паломники ніколи не вирушають у далеку та небезпечну подорож без пророцтва лами-оракула та спеціальної церемонії молитви. В даний час буддійськіритуалипаломництва складаються з наступних етапів: багаторазове обминання храму чи монастир за годинниковою стрілкою; падіння навзнак перед святинею, зазвичай тричі перед входом до монастиря чи храму; читання молитов, магічних мантр; подання до святині, висловлення вдячності паломника; омивання водою (у Тибеті, на відміну від Індії, досить поприскати кілька крапель на себе); віруючий отримує благословення шанованого лами, який торкається його голови, тим самим даруючи 
йому частинку святості або пропонує йому шовкову нитку червоного чи жовтого кольору, що має захисне значення для прочанина. Виконання, послідовність та порядок цих ритуалів суворо не регламентовані i більше залежать від релігійної завзятості та благочестя паломників.

Таким чином слід зазначити, що інтерес до буддизму в сучасному світі з кожним роком лише зростає, і причини цього криються як у процесах глобалізації, так ів якійсь прихованій привабливості цього древнього вчення. Для сотень мільйонів буддистів благоговійне ставлення до предмету поклоніння служить накопиченню благодаті, i та чи інша праведна людина $\epsilon$ заступником, який допомагає людині перервати цикл відродження. Щоб відчути дух буддизму, відчути його енергію, багато адептів Сіддхартхи Гаутама Шакьямуні відправляються в паломницьку подорож до буддистських священних місць, яка допомагає очистити душу, відчути особливу духовну атмосферу, торкаючись старовинних храмів. Сьогодні пам'ятки цієї релігії ретельно охороняються ченцями, а тому добре зберіглися. При тому створюються умови, в яких паломники можуть повністю зануритися в атмосферу буддизму. Екуменічна спрямованість західного буддизму, включення у практику елементів вчення найрізноманітніших шкіл і напрямків, відповідно, сприяє збільшенню кількості представників цієї релігії, тому можна припустити, що кількість паломників за межами Азії з часом лише буде збільшуватися.

Паломництво не так унікально і не є єдиним у своєму роді феноменом, а походить від більш широкої суспільної системи. Існує також думка, що визначає релігійний туризм як невід'ємну частину паломництва. Вчені, які поділяють таку думку, стверджують, що паломництво зародилося набагато раніше туризму в сучасній формі. Однак в країнах 3 важливими релігійними святинями і великим потоком паломництва $є$ чітка різниця між паломниками та туристами. Між тим все більше соборів, мечетей, релігійних музеїв і духовних пам'яток релігії, історії та культури стають частиною сучасної індустрії туризму (Долматов, 2001, с. 15) і грають важливу роль в мотивації відвідувань певних регіонів чи міст. Більшість релігійних пам'яток, які $\epsilon$ об'єктами туристичних показу, знаходяться під охороною своїх держав.

Сьогоднішні причини паломництва різні, починаючи від звичайної цікавості та закінчуючи поїздками до святинь своєї віри. Багато прочан спрямовуються до подорожі, щоб зміцнити віру. С й такі, що хочуть вилікуватися від хвороби та відвідують буквально всі святі місця планети - адже це часом єдиний шанс знайти здоров'я. В якості основних мотивів (установок віри) паломництва слідвиділити наступні: бажання помолитися і доторкнутися до чудотворної ікони, нетлінним мощам; сповідатися в культовому центрі або релігійному центрі, або у відомого релігійного діяча; виконати богоугодні роботи; зробити пожертвування; знайти і відчути благодать; вилікуватися від хвороби; виконати обітницю.

Сторіччя тому люди їхали також поклонитися святиням. Час проходить, а кількість мандрівних 3 причин віри не зменшилася, а навіть збільшилася. Тепер $\epsilon$ можливість відвідати святі місця без особливих труднощів. Як i туристи, які подорожують 3 різними цілями, паломники користуються послугами туристичної галузі: транспорт, проживання і харчування, розваги, туроператори і турагенти, які продають туристичну продукцію. Однак паломники часто користуються й іншими послугами: вони живуть при храмах, монастирях і містах, коли іноді добираються до місця призначення транспортними засобами, що надаються цими організаціями. При цьому паломники можуть виконувати певні завдання у вигляді слухняності i служіння, іноді такі вимоги для них стають обов'язковими. Вибір паломницьких турів вражає різноманітністю, від місць, які відомі в світовому релігійному масштабі, до іноді малих церков в селах мають велику святу силу, і віруючі знають їх і їдуть за тисячі кілометрів до цього місця, хоча населення села складає не більше сотні жителів. Але все це обумовлює релігійне паломництво як вид туризму.

\section{Висновки.}

Таким чином, необхідно визначити, що паломництво - це перспективний, але досить недостатньо досліджений вид туризму, який потребує розвитку й популяризації. Його особливість в тому, що він робить благотворний вплив не тільки на фізичний 
стан людини, але також на психологічний і духовний. Зовсім необов' язково бути глибоко релігійною людиною, щоб відправитися в паломництво: багато хто сприймає його просто як подорож або як виклик собі, здатність дізнатися щось нове про себе чи про навколишній світ.

Визначення туризму як діяльності ні в якому разі не поступається концепції паломництва. Виходячи 3 наукового визначення паломницьких та релігійних турів, ми можемо сказати, що діяльність, про яку можна сміливо говорити як про поїздку 3 паломницькою метою, не менш стосується туризму, ніж духовної діяльності. Й хоча паломництво насправді $\epsilon$ релігійною діяльністю, але воно регулюється законодавством про туризм. Однак радикальна відмінність паломника від туриста - в цілях поїздки, її мотивації, в молитовному настрої. Так, скажімо, концертний хоровий спів теж дуже близький до храмового, але це не одне і те ж саме.

Тому, плануючи паломництво, треба пам'ятати, що головна мета будь-якого паломництва - це не тільки прохання в молитві перед чудотворними іконами, мощами та іншими святинями на святій землі, але й поклоніння святим місцям, пов'язаним із земним життям Христа, Богородиці, апостолів, Будди, пророка Моххамеда та інших святих. Паломницькі подорожі можуть відрізнятися різним наповненням безпосередньо паломництвом та релігійним туризмом. Вивчаючи зміст будь-якої паломницької подорожі, можна зробити висновок, що вона, хоча i має свої особливості, але однаково стосується надання традиційних туристських послуг, як і інші тури.

Слід зазначити, що в більшості сучасних країн сфера релігійного туризму є досить розвиненою і прибутковою, та супроводжується державною підтримкою i приватними інвестиціями. Таким чином можна зробити висновок що, паломницький туризм цілком може вийти на міжнародний рівень і стати головною визначною пам'яткою як окремих регіонів, так і цілої країни та відігравати важливу економічну роль в розвитку певної території.

\section{БІБЛІОГРАФІЧНІ ПОСИЛАННЯ}

Бабкин А. В. Специальные виды туризма Ростов-на-Дону : Феникс, 2008. 252 с.

Биржаков М. Б. Введение в туризм: Учебное пособие. Санкт-Петербург : Издательский дом «Герда», 2000. 192 c.

Долматов Г. М. Международный туристический бизнес: история, реальность и перспективы. - Ростов на Дону : Феникс, 2001. 368 с.

Житенев С. Ю. Религиозное паломничество в христианстве, буддизме и мусульманстве: социокультурные, коммуникационные и цивилизационные аспекты. Москва : Индрик, 2012. 263 с.

Калужникова Е.А. Паломничество как ритуал. Известия Уральского государственного университета. T. 47. Вып. 12. Екатеринбург, 2006. С. 15.

Печерица Е. В., Шарафанова Е. Е. Паломнический туризм: сущностные аспекты. Современные проблемы науки и образования. 2014. № 6. URL: http://science-education.ru/ru/article/view?id=16486.

Расторгуев В.Н. Отношение к святыням и культура паломничества. Сборник материалов научнометодической конференции «Сотериологический смысл паломничества». 12 февраля 2007 г. Москва, 2007. C. 60-61.

Словарь православного паломника. Москва : 2007. 250 с.

Хадж 2020: когда пройдет и сколько будет стоить. URL: https://tj.sputniknews.ru/trend/khadzh palomnichestvo mekka tsena/

Хадж 2020: паломничество в Мекку. URL: https://tj.sputniknews.ru/trend/Tragedy_in_Mecca_25092015/.

Христов Т. Религиозный туризм : учебное пособие. Издательство: Academia, 2009. 288 с.

\section{REFERENCES}

Babkin, A. V. (2008). Special types of tourism. Rostov-on-Don: Phoenix [in Russian].

Birzhakov, M. B. (2000). Introduction to tourism. Sankt-Petetburg: Publishing house «Gerda» [in Russian].

Dictionary of the Orthodox Pilgrim. (2007). Moscow [in Russian].

Dolmatov, G. M. (2001). International tourism business: history, reality and prospects. Rostov-on-Don: Phoenix [in Russian]. 
Hajj 2020: pilgrimage to Mecca. (2020). Retrieved from https://tj.sputniknews.ru/trend/Tragedy_in Mecca 25092015/ [in Ukrainian].

Hajj 2020: when will it take place and how much will it cost. (2020). Retrieved from https://tj.sputniknews.ru/ trend/khadzh palomnichestvo mekka tsena/ [in Ukrainian].

Kaluzhnikova, E. A. (2006). Pilgrimage as a ritual. Bulletin of the Ural State University, 47 (12). Yekaterinburg [in Russian].

Khristov, T. (2009). Religious tourism. Textbook, Publisher: Academia [in Russian].

Pecheritsa, E. V., \& Sharafanova, E. E. (2014). Pilgrimage tourism: essential aspects. Modern problems of science and education, 6. Retrieved from http://science-education.ru/ru/article/view?id=16486 [in Russian].

Rastorguev, V. N. (2007). Relation to shrines and the culture of pilgrimage. Collection of materials of the scientific and methodological conference «Soteriological meaning of pilgrimage», February 12, 60-61 [in Russian].

Zhitenev, S. Yu. (2012). Religious pilgrimage in Christianity, Buddhism and Islam: socio-cultural, communication and civilizational aspects. Moskva: Indrik [in Russian].

\section{Zatsepina Nataly}

Ph.D., Assoc. Prof., https://orcid.org/0000-0003-1866-449X, Nat020375@gmail.com

Стаття надійшла / Article arrived: 24.12.2020

Схвалено до друку / Accepted: 20.01.2021 